\title{
FLUXES OF METHANE BETWEEN LANDFILLS AND THE ATMOSPHERE: NATURAL AND ENGINEERED CONTROLS
}

J. Bogner ${ }^{1}, M$. Meadows ${ }^{2}$, and P. Czepiel ${ }^{3}$

Argonne National Laboratory, Argonne, Illinois USA

${ }^{3}$ Harvard University, Cambridge, Massachusetts USA

\section{CONF-9706143-1 \\ RECEIVED}

JUL 071997

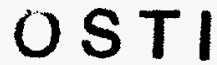

Abstract. Field measurement of landfill methane emissions indicates natural variability spanning more than seven orders of magnitude, from approximately 0.0004 to more than $4000 \mathrm{~g} \mathrm{~m}^{-2}$ day ${ }^{-1}$. This wide range reflects net emissions resulting from production (methanogenesis), consumption (methanotrophic oxidation), and gaseous transport processes. The determination of an "average" emission rate for a given field site requires sampling designs and statistical techniques which consider spatial and temporal variability. Moreover, particularly at sites with pumped gas recovery systems, it is possible for methanotrophic microorganisms in aerated cover soils to oxidize all of the methane from landfill sources below and, additionally, to oxidize methane diffusing into cover soils from atmospheric sources above. In such cases, a reversed soil gas concentration gradient is observed in shallow cover soils, indicating bidirectional diffusional transport to the depth of optimum methane oxidation. Rates of landfill methane oxidation from field and laboratory incubation studies range up to $166 \mathrm{~g} \mathrm{~m}^{-2}$ day ${ }^{-1}$, among the highest for any natural setting, providing an effective natural control on net emissions. It has been shown that methanotrophs in landfill soils can adapt rapidly to elevated methane concentrations with increased rates of methane oxidation related to depth of oxygen penetration, soil moisture, and the nutrient status of the soil.

Estimates of worldwide landfill methane emissions to the atmosphere have ranged from 9 to $70 \mathrm{Tg}$ $\mathrm{yr}^{-1}$, differing mainly in assumed methane yields from estimated quantities of landfilled refuse. At highly controlled landfill sites in developed countries, landfill methane is often collected via vertical wells or horizontal collectors. Recovery of landfill methane through engineered systems can provide both environmental and energy benefits by mitigating subsurface migration, reducing surface emissions, and providing an alternative energy resource for industrial boiler use, on-site electrical generation, or upgrading to a substitute natural gas. Manipulation of landfill cover soils to maximize their oxidation potential could provide a complementary strategy for controlling methane emissions, particularly at older sites where the methane concentration in landfill gas is too low for energy recovery or flaring. For the future, it is necessary to better quantify net emissions relative to rates of methane production, oxidation, and transport. Field measurements, manipulative studies, and model development are currently underway at various spatial scales in several countries.

\subsection{Introduction and Background}

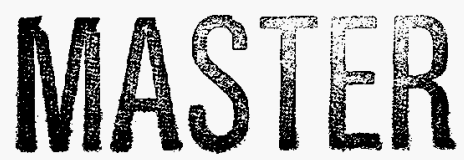

Global landfilling practices vary widely and are a major determinant of methane generation and emission rates at a given site. At most controlled landfills, refuse is placed in discrete cells covered by replaced natural soils of local derivation; thus it is appropriate to investigate the range of physical, chemical, and microbiological soil processes active in landfill settings. The rates and controlling variables in both spatial and temporal scales may differ from other terrestrial ecosystems, but the major processes involving gaseous transport and $\mathrm{C} / \mathrm{N}$ cycling are the same. In this paper, we will focus on net methane fluxes at the

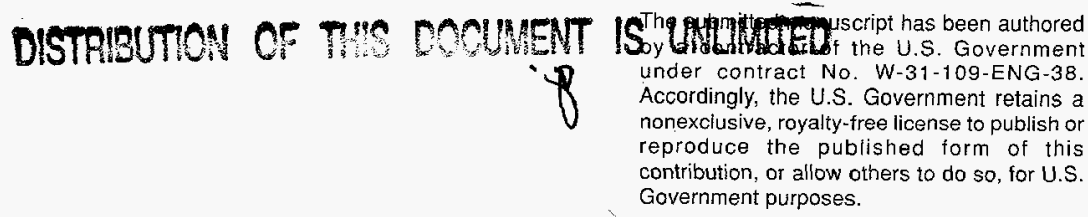




\section{DISCLAMMER}

Portions of this document may be illegible in electronic image products. Imsges are produced from the best available original document. 


\section{DISCLAIMER}

This report was prepared as an account of work sponsored by an agency of the United States Government. Neither the United States Government nor any agency thereof, nor any of their employees, make any warranty, express or implied, or assumes any legal liability or responsibility for the accuracy, completeness, or usefulness of any information, apparatus, product, or process disclosed, or represents that its use would not infringe privately owned rights. Reference herein to any specific commercial product, process, or service by trade name, trademark, manufacturer, or otherwise does not necessarily constitute or imply its endorsement, recommendation, or favoring by the United States Government or any agency thereof. The views and opinions of authors expressed herein do not necessarily state or reflect those of the United States Government or any agency thereof. 
soil/atmosphere interface. Because landfills produce large quantities of biogenic methane (methanogenesis), and landfill soils are characterized by high capacities for methane oxidation (methanotrophic oxidation), the realistic measurement and modeling of net methane emissions requires simultaneous consideration of production, consumption, and transport processes. Consideration of landfill emissions of other greenhouse gases or trace components of environmental concern (aromatics, chlorinated compounds) are beyond the scope of this paper but have been discussed elsewhere (Bogner et al. 1997b; Bogner and Spokas, 1996).

Estimates for global methane emissions from landfills range between 9 and $70 \mathrm{Tg}_{-1}^{-1}$ (Table 1). The most current estimate indicates a range of 19 to $40 \mathrm{Tg} \mathrm{yr}^{-1}$ (Doorn and Barlaz, 1995). It is important to note that none of the existing estimates are based on field measurement of emissions; rather, they rely on estimated rates of methane production applied to national statistics for landfilled refuse. In contrast, global estimates for methane emissions from other terrestrial ecosystems such as wetlands include a combination of "top down" [e.g., worldwide wetland areas] and "bottom up" approaches [e.g., field measurement of emissions/controlling variables] . Compared to other non-point terrestrial sources of methane (wetlands, rice production), landfills function as more of a closed system because of controlled burial of biodegradable organic materials. Landfills may be highly engineered to capture leachates and gases, occasionally with construction of pumped systems for commercial recovery of methane. Thus, unlike other terrestrial sources of atmospheric methane, the implementation of both engineered and natural controls must be considered with respect to their impact on net emissions. This paper will briefly review landfill methanogenesis, techniques and measured rates for direct measurement of landfill methane emissions, and rates of methane oxidation in landfill settings. At a given site, it is useful to consider the partitioning of methane generation into various pathways (Bogner and Spokas, 1993; 1995):

$$
\begin{gathered}
\mathrm{CH}_{4} \text { Generated }= \\
\mathrm{CH}_{4} \text { Emitted }+\mathrm{CH}_{4} \text { Oxidized to } \mathrm{CO}_{2}+ \\
\mathrm{CH}_{4} \text { Recovered by pumped systems }+\mathrm{CH}_{4} \text { Migrated }+ \\
\Delta \mathrm{CH}_{4} \text { Storage. } \\
\text { [units }=\text { mass per unit time] }
\end{gathered}
$$

Because an individual landfill can be considered a relatively closed methane system in comparison to surrounding ecosystems, quantification of the mass balance on methane shown above should be possible at well-controlled field sites. Ideally, lateral migration should be negligible. The delta storage term is necessary to include temporary internal methane storage. As will be discussed below, rates of methane generation, oxidation, and emissions can each vary by several orders of magnitude at a given site.

\subsection{Landfill Methanogenesis and Soil Gas Profiles}

Isotopic studies indicate that landfill methane is produced by both acetoclastic and carbon dioxide reduction pathways with some in situ methane oxidation (Bergamaschi and Harris, 1995; Bogner et al., 1995). Compared to other terrestrial ecosystems, landfills are characterized by higher rates of methane production and larger soil gas methane gradients from the deeper production zone to the soil-atmosphere interface. From laboratory incubations of landfill samples and fresh refuse samples, the maximum methane yields

from landfilled refuse are typically $0.06-0.1 \mathrm{~m}^{3} \mathrm{~kg}(\mathrm{dry})^{-1}$ (Bogner and Spokas, 1993; Table 2), depending on numerous factors, including water content, nutrient status, temperature, $\mathrm{pH}$, and properties of entrained 
soil. The maximum fraction of organic carbon converted to biogas carbon (methane and carbon dioxide) in landfills is generally $0.25-0.50$ in optimized laboratory studies (Bogner and Spokas, 1995). Reviews of landfill methanogenesis are contained in Halvadakis et al., 1983; AFRC, 1988; and Gendebien et al., 1992. Currently, large test cell studies in Sweden and England are producing methane at rates ranging from $0.002-0.016 \mathrm{~m}^{3} \mathrm{~kg}(\mathrm{dry})^{-1} \mathrm{yr}^{-1}$ (Nilsson et al., 1995; Campbell et al., 1995). The maximum methane yield since October, 1989, from the highest-producing Brogborough (England) test cell is $0.029 \mathrm{~m}^{3} \mathrm{~kg}(\mathrm{dry})$ (Campbell et al., 1995). Minimum rates, however, can be negligible in portions of landfill sites which are dry and isolated. The available free moisture at a given microsite is the medium through which degradable substrates, nutrients, and microorganisms interact. Thus, it is possible for rates within a given site to vary by two orders of magnitude or more, depending largely on localized moisture conditions and other factors such as organic loading rates, available nutrients, and neutralization potential (Bogner, 1990).

Soil gas methane concentrations in refuse below the soil cover are typically $50-60 \%(v / v)$, with the remainder mostly carbon dioxide. At sites without engineered gas recovery systems, the methane concentration gradient through the soil cover may thus range over more than 5 orders of magnitude. In landfills with pumped gas recovery systems, however, soil gas methane may remain closer to atmospheric levels through the soil cover materials. The convective influence of the pumped system lowers soil gas methane in the refuse sequence, resulting in lowered soil gas concentrations and retarding diffusive flux to the cover. Only in extreme cases of overpumping with forced air intrusion is there a direct convective influence of the gas recovery system on soil gases in the cover materials. In such cases, there is also the danger of starting internal landfill fires as well as a possibility of retarding methanogenesis in some portions of a given site. Figure 1 shows a variety of soil gas methane profiles from landfills with and without engineered gas control systems. Note that in the case of an optimized gas recovery system, there may be an inward methane gradient from the atmosphere to the zone of maximum methane oxidation rates. At such sites, the soil cover materials are functioning as a sink for rather than a source of atmospheric methane (Whalen and Reeburgh, 1990; Bogner et al., 1995; Bogner et al., 1997a)

In very wet landfills, Henry's Law partitioning of carbon dioxide to the aqueous phase may promote mixing ratios with even higher relative methane contents. In very recent landfilled refuse, hydrogen may also be quantifiable in deeper anaerobic zones. Often, low concentrations of atmospheric gases are present at the base of the cover materials, indicating that this is not a site of methanogenesis by strict anaerobes but rather lies within a mixing zone with deeper sites of methane production.

In cover soils that have been in place for several years, methanotrophic methane oxidation and nitrogen cycling processes may be well established. As in non-landfill soils, carbon dioxide from soil respiratory activity may attain values of 1 to $3 \%(\mathrm{v} / \mathrm{v})$ within the cover materials. Correspondingly, carbon dioxide production from methanotrophic activity may account for only a small fraction of the carbon dioxide produced by soil respiration. Oxygen, nitrogen, and argon are also present in cover soils, exhibiting inward gradients from atmospheric sources. At highly controlled sites with optimized gas recovery, a modified reduction sequence may be present across the cover materials, with maximum rates of methane oxidation in near surface zones above successively lower zones of optimum soil respiration, nitrous oxide production, and methane transport from refuse production zones (Bogner, unpublished data).

\subsection{Measurement of Landfill Methane Emissions}

Several techniques are available for field measurement of landfill methane emissions; a previous summary was given in Bogner and Scott (1995). Because of complex dynamics resulting in high spatial variability 
of methane generation, consumption, and transport processes, there is no single perfect technique. Rather, it is recommended that two or more techniques be used in tandem, ideally chosen to focus on different scales. In the field, several techniques applied over time are often needed to resolve questions pertaining to controlling variables. Techniques which have been used to date include:

(1) Above-ground techniques for larger area (thousands of $\mathrm{m}^{2}$ ) or whole landfill footprints, including micrometeorological techniques and a tracer method using SF6;

(2) Ground-surface enclosure techniques for individual measurements, typically at the scale of a $\mathrm{m}^{2}$ or less, including static and dynamic chambers; and

(3) Below-ground gradients for single-point measurements, where diffusive flux is calculated from vertical concentration profiles.

Static enclosure techniques have been the most widely used for the landfill setting. Their first use was reported by Kunz and $\mathrm{Lu}$ (1980) for methane fluxes from a New York site which averaged $0.4-0.6 \mathrm{~g} \mathrm{~m}^{-2}$ day $^{-1}$. Table 2 summarizes recent measurements, partially incorporating and updating a previous table contained in Bogner and Scott (1995). Major techniques and specific studies are discussed below. An overall range of 0.0006 to $3000 \mathrm{~g} \mathrm{~m}^{-2} \mathrm{day}^{-1}$ is indicated. This range is reasonable in the context of the wide range of methane yields discussed above as well as methane oxidation rates to be discussed below -- both may vary by several orders of magnitude in landfill settings.

In most cases, methane quantification is by gas chromatography (GC/FID), except for limited use of laser diode sensors in conjunction with micrometeorological and tracer methods (Hovde et al.,1995; McManus et al., 1989). Field FID instruments are not recommended for flux measurements, but may be suitable for preliminary screening of sites to establish experimental designs and for preliminary enclosure fluxes at sites with high flux rates and low concentrations of interferring hydrocarbons. For the future, Fourier Transform Infrared (FTIR) spectrometric techniques may be useful in landfill settings for an integrated determination of methane concentrations in the atmosphere above the landfill. However, for FTIR approaches, the measured methane concentrations above the landfill must provide sufficient contrast with ambient air methane and be coupled with appropriate dispersion models to calculate flux. Such models have not yet been developed and validated for landfill settings.

\subsection{Enclosure(Chamber) Methods}

Enclosure techniques can be used to measure methane fluxes from small areas of the landfill surface, typically less than $1 \mathrm{~m}^{2}$. Advantages include an appropriate scale for concurrent measurement of controlling variables (e.g., temperature, moisture), ability to determine the heterogeneity of surface emissions, and ready comparison with other results since this simple technique has been widely deployed in non-landfill settings for a variety of gases (Pearson et al., 1965; Kanemasu et al., 1974; Denmead, 1979; Sebacher and Harriss, 1982; Harriss et al, 1982; Rolston, 1986; Mosier, 1989; Hutchinson and Livingston, 1993). Disadvantages include small size and intensive labor requirements, although larger and more automated chambers are now beginning to be used by several research groups in non-landfill settings. Both static and dynamic enclosure methods are available; however, static methods have been more widely applied to the landfill setting. In addition, static enclosures can be used to determine net uptake of atmospheric methane (Whalen and Reeburgh, 1990), which can be important at landfills with optimized gas recovery systems (Bogner et al., 1995; Bogner et al., 1997a). In most landfills, the static method is preferable due to its simplicity. Robust collars for chambers are needed where the landfill cover soils contain large amounts of coarse fractions and for winter fluxes in climates where ground freezing occurs. The flux is calculated from the $\mathrm{dc} / \mathrm{dt}$ for a series of chamber concentrations and the chamber volume/area 
ratio. The dc/dt (positive slope for emissions; negative slope for atmospheric methane uptake) is calculated by linear regression of the methane concentration in four or five headspace samples taken over 30 minutes or less with a required correlation coefficient $[r]$ of 0.90 or higher.

Enclosure data can be statistically evaluated to determine whole landfill fluxes by establishing statisticallybased sampling schemes. Livingston and Hutchinson (1995) have suggested that descriptive statistics of spatial data based on the arithmetic mean are unbiased, regardless of the underlying distribution, if the number of samples is adequately large. In the landfill case, a number of samples in excess of 100 appears to satisfy this requirement. In most cases, a regular gridded sampling pattern is recommended, recognizing that small grid adjustments based on local topography and other obstructions may be necessary. These measurements should be performed during a period of minimal barometric pressure change, preferably over 1-2 days. An additional benefit of enclosure sampling is the ability to statistically characterize the heterogeneity of surface emissions. For example, as shown by Czepiel et al. (1996), the extent of spatial correlation among surface enclosure data can be analyzed using semivariogram analysis (Isaaks and Srivastava, 1989).

\subsection{Tracer Methods}

Tracer methods rely on concurrent concentration measurements for a gas of interest and an inert tracer released at a known rate; the concentration ratios of the two gases downwind can then be related to the ratio of their fluxes. Atmospheric tracer methods circumvent the problem of spatial heterogeneity by integrating whole area flux and are therefore a favored method for making whole landfill emission estimates. This method has been used successfully to characterize trace gas emissions from a number of natural and anthropogenic sources (Czepiel et al., 1996; Howard et al., 1992; Lamb et al., 1986). However, the applicability of tracer methods is limited by their relatively high cost, dependence on meteorological conditions, and the potential for interfering methane sources. Also, common tracers such as sulfur hexafluoride $\left(\mathrm{SF}_{6}\right)$ are themselves potent greenhouse gases, and additional atmospheric releases must be carefully controlled.

An inert tracer gas, most commonly $\mathrm{SF}_{6}$, is released from the emitting surface and measured downwind in the resulting plume together with the gas of interest. If the released tracer is well mixed in the source plume, then the methane emission rate can be obtained directly by the ratio method as:

$$
\mathrm{Qm}=\mathrm{Qt}(\mathrm{Cm} / \mathrm{Ct})
$$

where $\mathrm{Qm}$ is the methane flux rate, Qt is the SF6 tracer release rate, $\mathrm{Cm}$ is the measured methane mixing ratio above background, and $\mathrm{Ct}$ is the measured mixing ratio of the $\mathrm{SF}_{6}$ tracer. This method is restricted to situations with no interfering sources (e.g., where the plume of interest is not mixed with another nearby source). Also, sufficiently high methane concentrations in air are required from the source to contrast with background and permit measurement far enough downwind to ensure adequate mixing with the tracer gas. Atmospheric tracer methods circumvent the problem of spatial heterogeneity of the methane source by integrating whole area flux and are therefore a favored method for making whole landfill emission estimates. However, their potentially high cost, dependence on meteorological conditions, and the potential for interfering sources limits their applicability.

The tracer gas is released from a number of locations along the upwind border of the landfill on a line perpendicular to the direction of the prevailing wind. Landfills ranging in size from approximately 20 to 100 ha require 3 to 4 evenly-spaced release points to ensure proper emissions simulation. The plume can be located using a continuous analyzer for either methane or the tracer gas. The most cost effective 
approach currently favors the use of a continuous analyzer for $\mathrm{SF}_{6}$ tracer. Having identified the plume, samples collected at ground level at several locations across the plume should be analyzed for methane and $\mathrm{SF}_{6}$ by gas chromatographic techniques supplying the necessary ratio values to calculate methane flow (Czepiel et al., 1996). The systematic error associated with the tracer method can be estimated by quantifying the variability of each step in the process, in previous studies yielding an overall RSS uncertainty of approximately $\pm 17 \%$ (Lamb et al., 1995).

\subsection{Micrometeorological Methods}

Micrometeorological methods measure the turbulent transfer of gases from the ground surface to the lower atmosphere. They are capable of measuring fluxes across larger areas (1000's of $\left.\mathrm{m}^{2}\right)$ than enclosure methods with minimal disturbance to the underlying surface. The specific footprint is determined at the time of each measurement using experimental data. In addition, as more automated methods, they are especially useful for study of diurnal and seasonal flux variations. However, they require expensive and sophisticated instrumentation, more complex calculations, and surface constraints (relatively level terrain) which limit their application.

Only two types of micrometeorological methods have been applied to measurement of landfill methane fluxes: eddy correlation and gradient techniques. Eddy correlation is a direct measurement of flux density determined from vertical wind velocity and concentration fluctuations, requiring concurrent measurement of the surface energy balance. This method has been used at a Tennesee landfill (USA) using a fast-response methane sensor $\left(10 \mathrm{sec}^{-1}\right)$ based on the absorption of radiation generated with a near-infrared InGaAsP laser (Meyers et al., 1992; Hovde et al., 1995). The second method is an indirect gradient technique: flux is equal to the product of the vertical concentration gradient (obtained with conventional techniques) and a turbulent diffusivity coefficient. Gradient approaches have been used in the Netherlands in parallel with a dispersion model to estimate emissions from areas of $2000 \mathrm{~m}$; also, a comparison with static chambers was completed for the same study (Verschut, Oonk, and Mulder, 1991). In general, the results from the two micrometeorological techniques compared favorably with each other with the gradient method results exhibiting lower variability than the concurrent chamber results. However, the gradient method requires a wind speed $>1 \mathrm{~m} \mathrm{sec}^{-1}$ and was limited to an accuracy of about $20-30 \%$ due to various types of errors (Oonk, personal communication, 1994).

\subsection{Subsurface Gradient Techniques}

Subsurface gradient techniques using a simple Fick's Law calculation for vertical diffusive flux from measured soil gas concentration profiles were reported by Bogner (1992) for an uncontrolled California (USA) landfill. In that case, where fluxes were extremely high and oxidation was negligible, the calculated fluxes were approximately $50 \%$ higher than concurrently measured static enclosure results. Also, where high rates of methane consumption occur in cover soils, concentration profiles must be used with caution since the net profiles reflect both transport and consumption processes.

Soil gas concentration profiles for several gases, taken in parallel with direct methane flux measurements by methods discussed above, are helpful to suggest vertical zonation of various processes for subsequent biogeochemical modeling. Composite soil gas profiles can be developed by plotting the geometric mean for a time-series of probe data (Bogner et al., 1993; Bogner et al., 1995, 1997a). Vertical concentration gradients are also the basis for a 3D finite difference model which calculates landfill methane emissions as a result of transport and oxidation processes through a layered cover soil; the concentration of methane at the base of the cover is the major determinant for initial flux to the cover soil. In this model, termed Landfill Methane Emissions Model (LMEM), modified mass transfer coefficients are developed from field 
soil gas concentration profiles and physical properties to calculate the net positive methane flux to the atmosphere or negative flux from the atmosphere (Bogner et al., 1997a). Finally, a composite of gradient and tracer methods, using indigenous ${ }^{222} \mathrm{Rn}$ as a natural tracer, has been proposed by Dorr and Munnich (1990).

\subsection{Methanotrophic Methane Oxidation: An Important Control on Landfill Emissions}

Methane is one of the most abundant organic compounds on the planet. However the annual emission of 500-600 Tg into the atmosphere (both thermogenic and biogenic) (Subak et al., 1993; Khalil and Shearer, 1993) accounts for only a small fraction of the estimated global biogenic methane production. It follows that large quantities of methane are oxidized microbiologically to $\mathrm{CO} 2$ before the reaching the atmosphere (Higgins et al., 1981). Microbiological methane oxidation is carried out by methylotrophs. These are organisms capable of gaining energy from the oxidation of reduced carbon compounds containing one or more carbon atoms but no carbon-carbon bonds (Colby and Zatman, 1972). Methanotrophs are a class of methylotrophs which have the specific enzyme (methane monooxygenase) that allows them to oxidize methane (Anthony, 1982). There is an abundance of methanotrophs in the environment (Whittenbury et al., 1970). They can represent up to $8 \%$ of the total heterotrophic population; Whittenbury et al. (1976) reported methanotroph counts of $5 \times 10^{7} \mathrm{ml}^{-1}$ in some sediments. Thus methanotrophs constitute one of the major groups of free-living microorganisms, and their metabolic activities play a major role in maintaining low levels of methane in the atmosphere (Higgins et al., 1981). Mancinelli (1995) provided a recent review of methanotrophs in soils.

In most situations where methane diffuses into aerobic environments, large populations of aerobic methanotrophs can be found. Most have an obligate requirement for reduced single-carbon substrates and are gram-negative, obligate aerobic rods, vibrio or cocci. Their activity depends on the presence of sufficiently high concentrations of both methane and oxygen, and so they tend to be confined to fairly narrow horizontal bands within their habitat, limited in their distribution by the downward diffusion of atmospheric oxygen and the upward diffusion of methane.

Adamse et al. (1972) and Hoeks (1972) demonstrated methane oxidation activity around leaks in natural gas pipes. Mancinelli et al (1981) showed methane oxidation in soils above landfill sites and Mancinelli and McKay (1985) estimated that approximately $10 \%$ of the methane produced by a landfill is oxidized by the methanotrophic bacteria in landfill cover. From field measurements and modeling, Czepiel calculated that approximately $10 \%$ of methane was oxidized at a northeastern U.S. landfill (Czepiel et al., 1995).

Many factors affect the mass of methane oxidized as it passes through landfill cover soils; these factors vary between landfill sites; hence quantities of methane oxidized are site-specific. At present there is no generally-accepted estimate for the proportion of methane that is oxidized after it has been generated within landfills. The calculations in the current version of the Intergovernmental Panel on Climate Change (IPCC) methodology for calculating national landfill methane emissions (IPCC, 1995) do not take methane oxidation into account. However, oxidation has been incorporated into the proposed methodology under the current revisions. Some existing methods for estimating methane emissions include a factor related to methane oxidation. However, the factors chosen differ widely: Orlich (1990) chose 40 to 50\%; Aitchison et al. (1996) used a range of 20 to $40 \%$, depending on the type of landfill site; van Amstel et al. (1993) assumed $20 \%$, and US EPA (1993) used a factor of 10\%. Czepiel et al. (1996) measured a whole landfill oxidation rate of $10 \%$ at a New Hampshire (USA) site. 
Laboratory studies show that landfill cover soils have a potential to oxidize methane at rates several orders of magnitude above observed rates (Whalen et al., 1990 \& Kightley et al., 1995). Methane oxidation at most landfill sites is probably sub-optimal and it follows that optimizing methane oxidation in landfill cover soils may reduce emissions of this important greenhouse gas. Thus, study of the factors limiting biological methane oxidation in landfill cover soil is important. Additionally, the contribution of methane oxidation to reducing landfill methane emissions needs to be estimated to allow more accurate estimation of methane emissions from landfill sites both on the national and global scale. It is difficult to study landfill methane oxidation in situ but oxidation rates strongly influence net emissions. Since obtaining representative, reproducible field data from which to draw firm conclusions is difficult, most studies overcome this variability by controlled laboratory measurement of methane oxidation rates of landfill cover soils. Soil sampling does, however, disturb the microbial ecosystem, which will in turn affect methane oxidation rates.

Reported methane oxidation rates in landfill cover soils range seven over orders of magnitude, from $3.37 \mathrm{x}$ $10^{-9}$ to $1.02 \times 10^{-2} \mathrm{~g} \mathrm{~m}^{-2} \mathrm{~s}^{-1}$ (Table 3). This is a much wider range than rates reported for non-landfill soil environments $\left(2.3 \times 10^{-9}\right.$ to $\left.7.5 \times 10^{-8} \mathrm{~g} \mathrm{~m}^{-2} \mathrm{~s}^{-1}\right)$ (Whalen and Reeburgh, 1990; Adamsen and King, 1993), though the lower end of the ranges are similar. Physiological characteristics such as substrate affinity and optimal temperature of landfill methane-oxidizing communities are similar to communities from other natural environments (Whalen et al., 1990). Since methane oxidation by methanotrophs can only take place where oxygen and methane occur simultaneously, the diffusion of oxygen and methane to the soil microbial community is likely to be the most important factor affecting the rate of methane oxidation. Methane concentration profiles through landfill covers usually show reduced concentrations toward the surface while oxygen concentrations are reduced with increasing depth. Kightley et al. (1995) showed that methane oxidation potentials were greatest where the vertical profiles of methane and oxygen overlapped in soil microcosms. There was significant increase in soil organic matter, presumably derived from methanotrophic biomass, where methane oxidation rates were greatest. Previous studies have shown that methanotrophic soil communities are enriched in the presence of high methane concentrations, developing a high capacity for methane oxidation.

Soil moisture content appears to be a crucial factor affecting methane oxidation because it influences both the movement of gases through the soil and microbial activity. Kightley and Nedwell (1995) showed that methane oxidation is enhanced in well-drained soils with a sandy, open structure, allowing free movement of gases. Whalen et al. (1990) reported that deviations from the optimum moisture content $\left(\sim 11 \% \mathrm{H}_{2} \mathrm{O}\right)$ for methane oxidation in a landfill cover soil result in markedly-reduced methane oxidation rates. The same authors reported a methane oxidation rate for landfill cover soil in the laboratory of $45 \mathrm{~g} \mathrm{~m}^{-2} \mathrm{day}^{-1}$ (5.21 x $10^{-4} \mathrm{~g} \mathrm{~m}^{-2} \mathrm{~s}^{-1}$ ), among the highest reported for any environment. The soil microbial community had the capacity to rapidly oxidize methane at concentrations greater than $1 \mathrm{ppmv}$ (first order rate constant $[\mathrm{k}]=$ $\left.0.54 \mathrm{~h}^{-1}\right)$ to $104 \mathrm{ppm}\left(\mathrm{k}=-2.27 \mathrm{~h}^{-1}\right)$. There were no large differences between the landfill soil methaneoxidizing community and other methane-oxidizing communities, such as those in lake sediments. The methane oxidation capacity of the same soil when waterlogged $\left(41 \% \mathrm{H}_{2} \mathrm{O}\right.$ [wt/vol] ) was similar to rates reported for lake sediments. The same study also indicated that methane oxidation rates were temperaturedependent. The optimum temperature was $31^{\circ} \mathrm{C}$ : there was no activity at $46^{\circ} \mathrm{C}$ and a very low rate at 5 ${ }^{\circ} \mathrm{C}$; methane oxidation rates at $15^{\circ}$ and $20^{\circ} \mathrm{C}$ were similar and significantly lower than rates at $26^{\circ} \mathrm{C}$ (Whalen et al, 1990). Boeckx and Van Cleemput (1996) similarly found the optimum temperature for methane oxidation in a different landfill cover soil was $25-30^{\circ} \mathrm{C}$; the optimum moisture content was approximately $15 \%$. 
Studying soil microcosms in the laboratory, Kightley et al (1995) reported the highest methane oxidation rate yet, $10.4 \mathrm{~mol} \mathrm{CH} \mathrm{m}^{-2}$ day $\left(1.93 \times 10^{-3} \mathrm{~g} \mathrm{~m}^{-2} \mathrm{~s}^{-1}\right)$. Methane oxidation kinetics showed that a soil microbial community with a low methanotrophic capacity (Vmax of $258 \mathrm{nmol} \mathrm{g}^{-1}$ soil h$^{-1}$ ) but relatively high affinity (kapp of $1.6 \mathrm{mM}$ ) remained in $\mathrm{N}_{2}$-purged control microcosms, even after six months without methane. When purged with methane, a different microbial community developed which had a lower affinity (kapp of $31.7 \mathrm{mM}$ ) for methane but a greater capacity Vmax of $998 \mathrm{nmol} \mathrm{g}^{-1}$ soil h$^{-1}$ ) for methane oxidation. This reflected enrichment of an active high-capacity methanotrophic community. Adding nutrients such as sewage sludge enhanced methane oxidation, while amendment with $\mathrm{NH}_{4} \mathrm{NO}_{3}$ reduced methane oxidation capacity. In vitro experiments suggested that $\mathrm{NH}_{4} \mathrm{NO}_{3}$ additions $\left(10\right.$ and $71 \mathrm{~mol} \mathrm{~g}^{-1}$ soil) inhibited methane oxidation by a non-specific ion effect rather than by specific inhibition by $\mathrm{NH}_{4}$ (Kightley et al., 1995). It follows that landfill cover soil could be engineered to optimize methane oxidation. However, at present, landfill caps and cover soils are not designed or engineered with methane oxidation in mind. In some developed and developing countries, landfills will have little or no cover soil or cover soil of very poor quality where, during dry periods, dessication cracks may form unless they are irrigated or tilled. Methane venting through such cracks in a landfill cover most likely will not reside in the cover for long enough to be oxidized.

Bogner et al. (1995) measured methane oxidation rates of $0.0004 \mathrm{~g} \mathrm{~m}^{-2}$ day $\left(4.63 \times 10^{-9} \mathrm{~g} \mathrm{~m}^{-2} \mathrm{~s}^{-1}\right)$ in landfill cover soils incubated in vitro with headspace methane at ambient levels (1.6 ppmv). In the same study, the potential for methane oxidation in the same soil was $8.1 \mathrm{~g} \mathrm{~m}^{-2}$ day ${ }^{-1}\left(8 \times 10^{-5} \mathrm{~g} \mathrm{~m}^{-2} \mathrm{~s}^{-1}\right)$ when the headspace methane was $3.5 \%(\mathrm{v} / \mathrm{v})$. If the rate of methane oxidation exceeds the flux of methane from the waste into the soil cover, and there is sufficient oxygen diffusing into the soil, there may be a net oxidation of atmospheric methane. Thus, under special circumstances, landfills may be a sink for atmospheric methane. Bogner et al. (1995) reported negative fluxes under enclosed chambers on the surface of a landfill with a gas recovery system. Monitored soil gas pressures indicated that the direct convective influence of wells on soil gas transport and methane emissions was negligible.

The effects of moisture, temperature, and organic carbon content on methane oxidation rates have been studied by Czepiel et al. (1996b), Borjesson and Svensson (1996), and Bogner (1997a). Czepiel et al. (1996b) found optimum oxidation rates corresponding to approximately $16 \%$ moisture content and nonlinearly increasing oxidation rates corresponding to increasing temperatures up to $36^{\circ} \mathrm{C}$. They further developed a model for whole-landfill oxidation which incorporates both laboratory incubation results and field measurements of emissions. Borjesson and Svensson (1996) demonstrated relationships among methane oxidation rate, soil organic carbon content, temperature, and other variables, which they combined in a multiple regression model. Bogner (1997a), in field studies of landfill soils with high methane-oxidizing capacity, observed a direct kinetic response of methane oxidation rates to changing methane concentrations which was more significant than temporal changes in temperature and moisture (Figure 2). Table 4 summarizes observed kinetic constants from studies of landfill methane oxidation. A wide range of kinetic constants have been reported from landfill studies, suggesting that multiple trophic groups of methanotrophs are active in landfill settings.

To summarize, the soil microbial community adapts rapidly to elevated methane concentration and can effectively reduce methane emissions from the landfill surface. The capacity for methane oxidation is related to depth of oxygen penetration and to the nutrient status of the soil. The capacity of the soil to 
respond to methane can be enhanced by amendment with a nutrient source such as sewage sludge. At many large modern landfill sites in developed countries, landfill methane is often collected and burnt for safety and environmental reasons. Manipulation of landfill cover soils to maximise their methane oxidation potential might provide a complementary strategy for controlling methane emissions, particularly at older sites where the methane concentration in landfill gas is too low for energy recovery or flaring.

\subsection{Conclusions}

Rates of methanogenesis and methanotrophy in landfills are the highest measured for any "natural" environment. The wide range of net observed methane emissions (including negative fluxes, or net oxidation of atmospheric methane) reflects the wide range of rates for both processes, which are often suboptimal in landfill settings. Control of landfill methane through engineered systems can provide both environmental and energy benefits by mitigating subsurface migration and furnishing an alternative energy resource. High capacities for methane oxidation can develop due to high historic methane concentrations in aerated landfill cover soils. It seems possible that such cover soils might provide a convenient field laboratory for intensive in situ study of methane oxidation applicable to other terrestrial soil settings. Better estimates of worldwide landfill methane emissions are needed which consider the wide range of observed emissions and methane oxidation rates.

\section{Acknowledgements}

This paper has been previously accepted for publication in Soil Use and Management. The authors wish to acknowledge the support of their respective employers.

\section{References}

AGRICULTURAL AND FOOD RESEARCH COUNCIL(AFRC) INSTITUTE OF FOOD RESEARCH. 1988. A basic study of landfill microbiology and biochemistry. ETSU Report B 1159. U.K. Dept. of Energy Renewable Energy Research and Development Programme.

AITCHISON, E.M., MILTON, M., WENBORN, M.J., MEADOWS, M.P., MARLOWE, I.T., MIKKELSEN, M., HARRIES, C., AND POCOCK, R. 1996. A methodology for updating routinely the annual estimate of methane emissions from landfill sites in the UK.. ETSU Report RYWA/18678001/R/4, Prepared for UK Department of the Environment.

ADAMSEN, A.P.S. \& KING, G.M. 1993. Methane consumption in temperate and subarctic forest soils: rates, vertical zonation and responses to water and nitrogen. Applied and Environmental Microbiology 59, $485-490$.

ADAMSE, A.D., HOEKS, J., DEBONT, J.A.M., \& VAN KESSEL, J.F. 1972. Microbial activities in soils near natural gas leaks. Arkiv fur Mikrobiologie 83, 31-35.

AERC. 1991. Field investigations of methane oxidation. Department of the Environment (UK) Controlled Waste Management Research Programme report CWM 042/89 pp

ANTHONY, C. 1982. The biochemistry of methylotrophs. Academic Press, London. 
BERGAMASCHI, P. \& HARRIS, G.W. 1995. Measurement of stable isotope ratios

$\left({ }^{14} \mathrm{CH} 4 /{ }^{12} \mathrm{CH} 4 ;{ }^{12} \mathrm{CH}_{3} \mathrm{D} /{ }^{12} \mathrm{CH}_{4}\right)$. Global Biogeochemical Cycles 9, 439-447.

BNGEMER, H.G. \& CRUTZEN, P.J. 1987. The production of methane from solid wastes. Journal of Geophysical Research 92(D2), 2182-2187.

BOECKX, P. \& VAN CLEEMPUT, O. 1996. Methane oxidation in a neutral landfill cover soil: influence of moisture content, temperature, and nitrogen-turnover. Journal of Environmental Quality 25, 178-183.

BOGNER, J. 1990. Controlled study of landfill biodegradation using modified BMP assays. Waste Management and Research 8, 329-352.

BOGNER, J. 1992. Anaerobic burial of refuse in sanitary landfills: increased atmospheric methane and implications for increased carbon storage. Ecological Bulletins (Copenhagen) 42, 98-108.

BOGNER, J., \& SCOTT, P. 1995. Landfill methane emissions: guidance for field measurements. Final report to International Energy Agency Expert Working Group on Landfill Gas, published by Technical University of Lulea, Sweden.

BOGNER, J., \& SPOKAS, K. 1993. Landfill methane: rates, fates, and role in global carbon cycle. Chemosphere 26(1-4), 369-386.

BOGNER, J., \& SPOKAS, K. 1995. Carbon storage in landfills. In: Soils and global change (Lal, R., et al., eds), Advances in Soil Science, CRC Lewis Publishers, Boca Raton, Florida, pp. 67-80.

BOGNER, J., \& SPOKAS, K. 1996. Field measurement of methane and NMOC emissions: sources, sinks and implications for emissions modeling. In: Proceedings SWANA $19^{\text {th }}$ Landfill Gas Symposium, March, 1996, North Carolina, Solid Waste Association of North America, Silver Spring, Maryland.

BOGNER, J., SPOKAS, K., \& BURTON, E. 1997a. Kinetics of methane oxidation in a landfill cover soil: measured rates, results of a whole-landfill oxidation experiment, and modeling of net methane emissions. Environmental Science and Technology, accepted.

BOGNER, J., SPOKAS, K., NIEMANN, M., NIEMANN, L., AND GRANFIELD, A., 1997b. Field Measurement of Methane and Non-Methane Organic Compound (NMOC) Emissions at the Greene Valley Landfill. Proceedings Wastetech '97 Conference, National Solid Waste Management Association, Washington, D.C.

BOGNER, J., SPOKAS, K., BURTON, E., SWEENEY, R., \& CORONA, V. 1995. Landfills as atmospheric methane sources and sinks. Chemosphere 31, 4119-4130.

BOGNER, J., SPOKAS, K., \& JOLAS, J. 1993. Comparison of measured and calculated methane emissions at Mallard Lake Landfill, DuPage County, Illinois (USA). In: Proceedings Sardinia' 93 International Landfill Conference, University of Cagliari, Sardinia, pp. 605-616.

BOGNER, J., SWEENEY, R.E., COLEMAN, D., HUITRIC, R., AND RIRIE, G.T. 1995. Using isotopic and molecular data to model landfill gas processes. Waste Management and Research 14, 367-376. 
BORJESSON, G., \& SVENSSON, B. 1993. Interactions between methane oxidation and the formation of nitrous oxide in a landfill cover soil. In: Proceedings Sardinia '93 International Landfill Conference, University of Cagliari, Sardinia, pp. 729-733.

BORJESSON, G., \& SVENSSON, B. 1996. Modellering av methanemissioner from ett avfallsupplag. In: Symposium om svensk upplagsforskning 1996 (A. Lagerkvist, ed.), RVF Publikation nr 96:1, Svenska Renhallningsverks-Foreningens Service AB, Malmo, Sweden, pp. 37-50 (in Swedish).

CAMPBELL, D., CAINE, M., MEADOWS, M., \& KNOX, K. 1995. Enhanced landfill gas production at large-scale test cells. Addendum to: Proceedings Sardinia '95 International Landfill Conference, University of Cagliari, Sardinia.

CROFT, B., AND EMBERTON, R. 1989. Landfill gas and the oxidation of methane in soil. Department of the Environment (UK) Controlled Waste Management Research Programme report CWM 049/89.

CZEPIEL, P., MOSHER, B., HARRISS, R., SHORTER, J.H., MCMANUS, J.B., KOLB, C.E., ALLWINE, E., \& LAMB, B. 1996. Landfill methane emissions measured by enclosure and atmospheric tracer methods. Journal of Geophyical. Research 101(D11), 16711-16719.

CZEPIEL, P., MOSHER, B., CRILL, P., \& HARRISS, R. 1996. Quantifying the effect of oxidation of landfill methane emissions. Journal of Geophyical. Research 101(D11), 16721-16729.

DENMEAD, O.T. 1979. Chamber systems for measuring nitrous oxide emission from soils in the field. Soil Science Society of America Journal 43, 89-95.

DOORN, M. \& BARLAZ., M. 1995. Estimate of global methane emissions from landfills and open dumps. U.S. Environmental Protection Agency report no. EPA-600/R-95-019. Prepared for U.S. EPA Office of Policy, Planning, and Evaluation, Washington, D.C.

DORR, H. \& MUNNICH, K.O. $1990 .{ }^{222}$ Rn flux and soil air concentration profiles in West Germany Soil ${ }^{222} \mathrm{Rn}$ as tracer for gas transport in the unsaturated soil zone. Tellus 42B, 20-28.

HARRIS, R.C., SEBACHER, D.I., \& DAY, F.P. 1982. Methane flux in the Great Dismal Swamp. Nature 297, 673-674.

INTERGOVERNMENTAL PANEL ON CLIMATE CHANGE. 1995. Greenhouse gas Inventory reporting Instructions-Workbook and reference Manual. UNEP, WHO, OECD, IEA. IPCC Guidelines for National Greenhouse Gas inventories, Vols 1-3.

GENDEBIEN, A., PAUWELS, M., CONSTANT, M., LEDRUT-DAMANET, M.J., NYNS, E.J., WILLUMSEN, H.C., BUTSON, J., FABRY, R., FERRERO, G.L. 1992. Landfill Gas: From Environment to Energy. Final Report EUR 14017/1 Directorate General for Energy, Commission of the European Communities. Luxembourg.

HALVADAKIS, C.P., ROBERTSON, A.P. \& LECKIE, J.O. 1983. Landfill methanogenesis: literature review and critique. Technical Report no. 271. Dept. of Civil Engineering, Stanford University, California. 
HIGGINS, I.J., BEST, D.J., HAMMOND, R.C., \& SCOTT, D. 1981. Methane-oxidizing microorganisms. Microbiology Reviews 45, 556-590.

HOEKS, J., 1992. Changes in composition of soil air near leaks in natural gas mains. Soil Science 113 (1), 46-45.

HOWARD, T., LAMB., B., \& ZIMMERMAN, P. 1992. Measurement of VOC emission fluxes from waste treatment and disposal systems using an atmospheric tracer flux, Journal of Air and Waste Management. Association 42, 1336-1344.

HOVDE, D.C., STANTON, A.C., MEYERS, T.P., AND MATT, D.R. 1995. Methane emissions from a landfill measured by eddy correlation using a fast-response diode laser sensor. Journal of Atmospheric Chemistry 20(2), 141-162.

HUTCHINSON, G.L. \& LIVINGSTON, G.P. 1993. Use of chamber systems to measure trace gas fluxes. In: Agricultural ecosystem effects on trace gases and global climate change. American Society of Agronomy Special Publication No. 55. Madison, Wisconsin. pp. 63-78

ISAAKS, E.H. \& SRIVASTAVA, R.M. 1989. An Introduction to Applied Geostatistics, 561 pp., Oxford University Press, New York.

JONES, H.A., \& NEDWELL, D.B. 1993. Methane emission and methane oxidation in land-fill cover soil. FEMS Microbiology Ecology 102, 185-195.

KANEMASU, E.T., POWERS, W.I., \& SIJ, J.W. 1974. Field chamber measurements of CO2 flux from soil surface. Soil Science 118, 233-237.

KHALIL, M.A.K. \& SHEARER, M. 1993. Sources of Methane, In: Atmospheric methane: sources, sinks, and role in global change (Khalil, M.A.K., ed.), Springer-Verlag, Berlin, pp. 180-197.

KIGHTLEY, D., NEDWELL, D.B., \& COOPER, M. 1995. Capacity for methane oxidation in landfill cover soils measured in laboratory-scale microcosms. Applied and Environmental Microbiology 61, $592-601$.

KUNZ, C. \& LU, A.-H. 1980. Methane production rate studies and gas flow modeling for the Fresh Kills Landfill. New York State Energy Research and Development Administration Report No. 80-21. Albany, New York.

LANGLEY, A., WILLIAMS, C., \& BARRATT, P. 1991. Stimulation of methane oxidation in soils. Department of the Environment (UK) Controlled Waste Management Research Programme report CWM $021 / 89 \mathrm{pp}$

LAMB, B., WESTBERG, H., \& ALLWINE, E. 1986. Isoprene emission fluxes determined by atmospheric tracer techniques. Atmospheric Environment 20, 1-8.

LAMB, B. ET AL. 1995. Development of atmospheric tracer methods to measure methane emissions from natural gas facilities and urban areas. Environ. Sci.Technol. 29, 1468-1479. 
LIVINGSTON, G.P. \& HUTCHINSON, G.L. 1995. Enclosure-based measurement of tracegas exchange: Applications and sources of error, In: Biogenic Trace Gases: Measuring Emissions from Soil and Water (P.A. Matson and R.C.Harriss, eds.), Blackwell Scientific, Cambridge, Mass. 360 p.

MANCINELLI, R. 1995. The regulation of methane oxidation in soil. Annual Reviews in Microbiology 49, 581-605.

MANCINELLI, R.L., \& MCKAY, C. 1985. Methane oxidizing bacteria in sanitary landfills. In: Biotechnological Advances in Processing Municipal Wastes for Fuels and Chemicals (A.A. Antonopoulos, ed.). Argonne National Laboratory Report ANL/CNSV-TM-167, also published by Noyes Publications, Park Ridge, NJ., pp. 437-450.

MANCINELLI, R.L., SHULLS, W.A., \& MCKAY, C.P. 1981. Methane oxidizing bacteria used as an index of soil methane concentration. Applied and Environmental Microbiology 42, 70-73.

MCMANUS, J.B., KEBABIAN, \& KOLB, C.E. 1989. Atmospheric methane measurement instrument using a Zeeman-split He-Ne laser. Appl. Opt. 28:5016-5023.

MCMANUS, J.B., SHORTER, J.H., KOLB, C.E., LAMB, B.K., SIVERSON, R., ALLWINE, E., WESTBERG, H.H., MOSHER, B.W., HARRISS, R.C., \& HOWARD, T. 1994. Results of tracer measurements of methane emissions from natural gas system facilities. Proceedings International Workshop on Environmental and Economic Impacts of Natural Gas Losses, March, 1994, Prague, Czech Republic.

MEYERS, T.P., HOVDE, D.C., STANTON, A.C.., \& MATT, D.R. 1992. Micrometeorological measurements of methane emission rates from a sanitary landfill. National Oceanic and Atmospheric Administration (NOAA) ATDL Contribuion No. 92/2, Oak Ridge, Tennessee.

MOSIER, A.R. 1989. Chamber and isotope techniques. Ir: Exchange of trace gases between terrestrial ecosystems and the atmosphere (Andreae, M.O., and D.S. Schimel eds.) John Wiley and Sons, Berlin, pp. 175-187.

NILSSON, P., KARLSSON, H., LAGERKVIST, A., \& MEIJER, J.E. 1995. The coordinated test cell program in Sweden. In: In: Proceedings Sardinia '95 International Landfill Conference, University of Cagliari, Sardinia, pp. 603-614.

NOZHEVNIKOVA, A.N., LIFSHITZ, A.B., LEBEDEV, V.S., \& ZAVARIN, G.A. 1993. Emissions of methane into the atmosphere from landfills in the former USSR. Chemosphere 26(1-4), 401-417.

ORLICH, J. 1990. Methane emissions from landfill sites and waste water lagoons. In International Mining Workshop on Methane Emissions from Natural gas Systems, Coal Mining and Waste management Systems, April 9-13, 1990, Washington D.C.

PEARSON, J.E., RIMBEY, D.H., \& JONES, G.E. 1965. A soil gas emanation measurement system used for radon-222. Journal of Applied Meteorology 4:349-356.

REINHART, D.R. \& PALADUGU, P. 1993. Estimation of landfill gas emissions at the Alachua County Southwest Landfill. Interim Report to the University of Florida from the Civil and Environmental Engineering Dept., University of Central Florida, Orlando, Florida. 
REINHART, D.R., COOPER, C.D., RUIZ, N.E., \& BOGERT, R.P. 1994a. Estimation of landfill gas emissions at the Orange County, Florida Landfill. Interim Report. April 15, 1994.

REINHART, D.R., PALADUGU, P., PALUMBO, D., \& LEYDEN,V. 1994b. Estimation of landfill gas emissions at the Alachua County, Florida, Southwest Landfill. Final Report.

RICHARDS, K. 1989. Landfill gas: working with gaia. Biodeterioration Abstracts. 3, 525-539.

ROLSTON, D.E. 1986. Gas flux. In: Methods of soil analysis: Part 1, Physical and mineralogical methods, 2nd edition. (A. Klute, ed.) American Society of Agronomy/Soil Science Society of America, Madison, Wisconsin, pp. 1103-1119.

SEBACHER, D.I. \& HARRISS, R.C. 1982. A system for measuring methane fluxes from inland and coastal wetland environments. Journal of Environmental Quality 11, 34-37.

SUBAK, S., RASKIN, P. \& VON HIPPEL, D. 1993. National greenhouse gas accounts: current anthropogenic sources and sinks. Climatic Change 25, 15-58.

U.S. ENVIRONMENTAL PROTECTION AGENCY. 1993. Methane emissions from landfills. In Anthropogenic methane emissions in the United States: Estimates for 1990. Report to Congress. EPA Report no. 430-R-93-003. EPA Office of Air and Radiation, Washington, D.C.

VAN AMSTEL, A.R., SWART, R.J., KROL, M.S., BECK, J.P., BOUWMAN, A.F., \& VAN DER HOEK, K.W. 1993. Methane: the other greenhouse gas. Research and policy in The Netherlands. RIVM report No. 481507001.

VERSCHUT, C., OONK, J., AND MULDER, W. 1991. Broeikasgassen uit vuilstorts in Nederland (Greenhouse gases from landfills in the Netherlands). TNO-Report 91-410, published by Instituut voor Milieu- en Energietechnologie TNO (IMET), Apeldoorn, the Netherlands (In Dutch).

WHALEN, S.C., \& REEBURGH, W.S. 1990. Consumption of atmospheric methane by tundra soils. Nature 346, 160-162.

WHALEN, S.C., REEBURGH, W.S., \& SANDBECK, K.A. 1990. Rapid methane oxidation in landfill cover soil. Applied and Environmental Microbiology 56, 3405-3411.

WHITTENBURY, R., PHILLIPS, K.C., \& WILKINSON, J.F. 1970. Enrichment, isolation and some properties of methane-utilising bacteria. Journal of General Microbiology 61, 205-218.

WHITTENBURY, R., COLBY, J., DALTON, H., \& REED, H.L. 1976. Biology and ecology of methane oxidizers. In: Symposium on microbial production and utilisation of gases (H2, CH4, CO) (H.G. Schlegel, G. Gottschalk and N. Pfennig eds.), Gottingen. Akademie der Wissenschaften, Gottingen. pp $281-292$. 


\section{List of Tables.}

Table 1. Historic Estimates for Global Landfill Methane Emissions.

Table 2. Landfill Methane Emissions Measurements. Selected data from recent literature and unpublished sources.

Table 3. Landfill Methane Oxidation Rates of Landfill Cover Soils. Selected data from the literature. Laboratory in vitro incubations of cover soils unless otherwise stated.

Table 4. Landfill Methane Oxidation Kinetic Constants. Selected data from recent literature. 
Table 1. Historic Estimates for Global Landfill Methane Emissions.

Estimated Emissions $\left(\operatorname{Tg~yr}^{-1}\right)$ Source $\quad$ Basis

$19-40$

33

$9-18$

$30-70$
Doorn and Barlaz, 1995

Orlich, 1990

Richards, 1989

Bingemer and

Crutzen, 1987
Used current estimates for per capita refuse generation and \% landfilled; developed country-based estimates based on urban, rural population; landfill practices; and waste composition.

Used estimates for per capita refuse generation; assumed net methane generation (reduced to allow for methane oxidation) of either $0.086 \mathrm{~kg}$ methane per $\mathrm{kg}$ refuse (developed countries) or $0.030 \mathrm{~kg}$ methane/ $\mathrm{kg}$ refuse (developing countries).

Used estimates for refuse generation proportional to GDP (gross domestic product); assumed $80 \%$ landfilled and steady-state methane generation of 0.036 $\mathrm{kg}$ methane per $\mathrm{kg}$ refuse.

Used current (mid-1980's) estimates for landfilled refuse; assumed yield of $0.1 \mathrm{~kg}$ methane $/ \mathrm{kg}$ refuse with all vented to atmosphere (20\% degradable organic carbon with conversion rate of $80 \%$; steady-state methane generation from historic quantities of refuse equal to current amounts). 
Table 2. Landfill Methane Emissions Measurements.

Selected data from recent literature and unpublished sources.

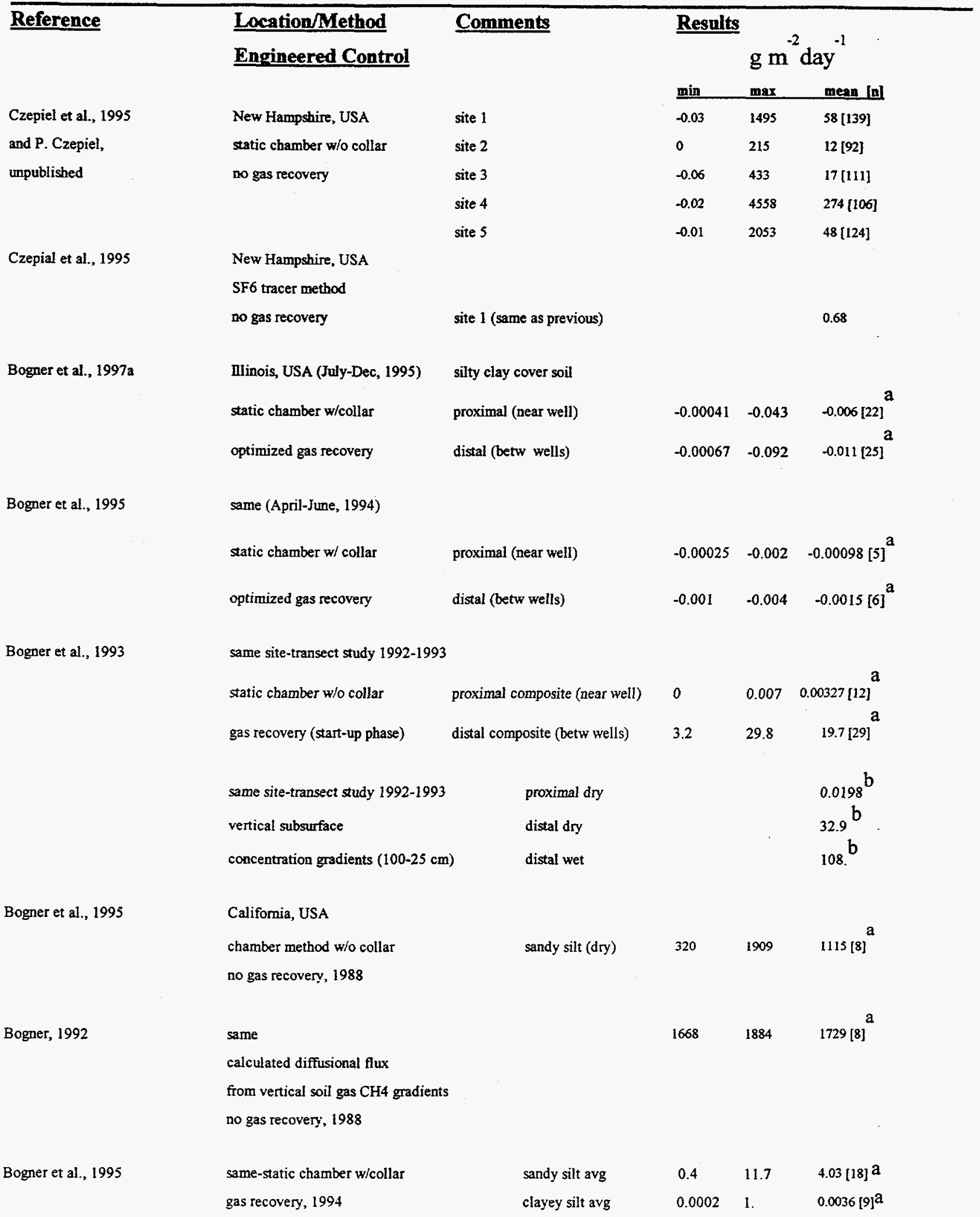


Table 2. (continued)

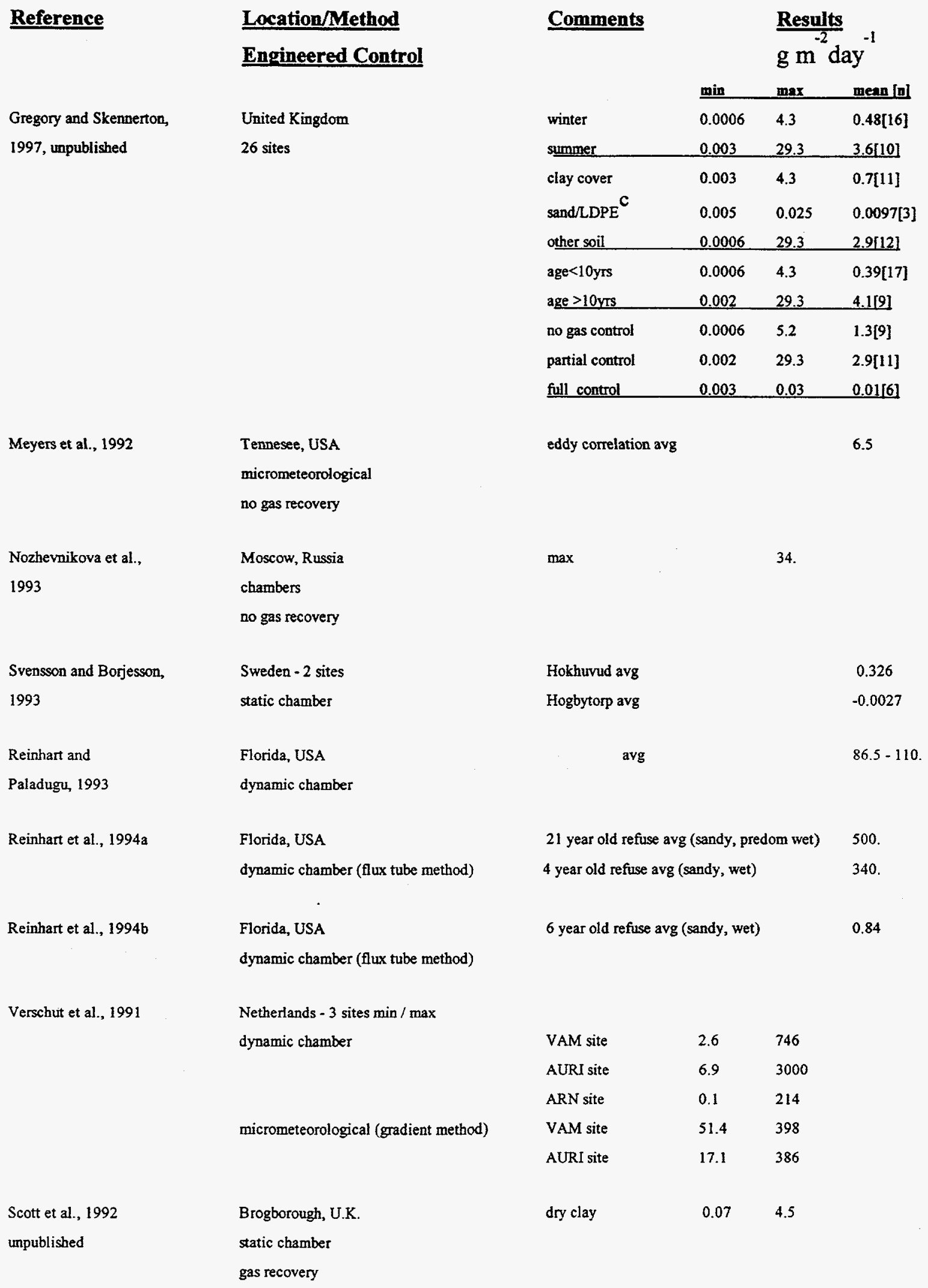


Table 2. (continued)

Notes for Table 2.

a. Number of values reflect daily means (2-6 fluxes / day).

b. Based on geometric mean soil gas $\mathrm{CH}_{4}$ profile for 1992-1993.

c. Low density polyethylene. 
Table 3. Landfill Methane Oxidation Rates of Landfill Cover Soils

Selected data from the literature. Laboratory in vitro incubations of cover soils unless otherwise stated.

Reference Methane Oxidation Rate $\left(\mathrm{g} \mathrm{m}^{-2} \mathrm{~s}^{-1}\right) \quad$ Comments
AERC (1991)
$1.08 \times 10^{-6}$ to $3.19 \times 10^{-6}$

Boeckx and Van

$6.6 \times 10^{-9}$

Maximum rate at

Cleemput (1996)

optimum moisture

and temperature,

10 ppmv $\mathrm{CH}_{4}$ initial

Bogner et al.

$4.63 \times 10^{-9}$

(1995)

$9.38 \times 10^{-5}$

1.6 ppmv $\mathrm{CH}_{4}$ initial

$3.5 \%(\mathrm{v} / \mathrm{v}) \mathrm{CH}_{4}$ initial

(field in vitro )

Croft \& Emberton $\quad 7.11 \times 10^{-6}$

Subsamples from

(1989)

soil columns; $\mathrm{O}_{2}$

and $\mathrm{CH}_{4}$ excess

Figueroa (1993)

$4.69 \times 10^{-4}$

$10 \%(v / v) \mathrm{CH}_{4}$ initial

Jones \& Nedwell $\quad 3.37 \times 10^{-9}$ to $8.33 \times 10^{-5}$

$12.5 \%(v / v) \mathrm{CH}_{4}$ initial

(1993)

Kightley et al. $\quad 1.06 \times 10^{-3}$ to $1.93 \times 10^{-3}$

Steady-state oxidation (1995) rate in microcosms purged with $5 \mathrm{ml} \mathrm{min}$ $\mathrm{CH}_{4}$ for up to 6 months

Whalen (1990) $5.21 \times 10^{-4}$

$7.7 \%(v / v) \mathrm{CH}_{4}$ initial 
Table 4. Landfill Methane Oxidation Kinetic Constants

Selected data from recent literature.

\begin{tabular}{lccc}
\hline$K_{M}$ & $V_{\max }$ & Reference & Notes \\
$(p p m v)$ & $\left(n m o l ~ \mathbf{~ h r}^{-1} \mathbf{g}^{-1}\right.$ dry soil $)$ & \\
\hline
\end{tabular}

\begin{tabular}{|c|c|c|c|}
\hline 1800 & 136 & Whalen et al., 1990 & $\begin{array}{l}\text { Laboratory incubations } \\
\text { of cover soil } \\
\text { (California, USA) }\end{array}$ \\
\hline $195-5847$ & $40-2594$ & Czepiel et al., 1996 & $\begin{array}{l}\text { Laboratory incubations } \\
\text { of cover soil } \\
\text { (New Hampshire, USA) }\end{array}$ \\
\hline $\begin{array}{l}49-2830 \\
88-2416 \\
399-6067 \\
402-6912\end{array}$ & $\begin{array}{l}12-1011 \\
21-968 \\
110-2885 \\
86-3371\end{array}$ & Czepiel et al., unpublished & $\begin{array}{l}\text { Laboratory incubations } \\
\text { of cover soil (New } \\
\text { Hampshire and } \\
\text { Massachusetts, USA) }\end{array}$ \\
\hline 45.0 & 5.6 & Bogner et al., 1997a & $\begin{array}{l}\text { Composite field } \\
\text { incubations plus negative } \\
\text { fluxes(Illinois, USA) where } \\
\text { initial } \mathrm{CH}_{4}<160 \mathrm{ppmv}(\mathrm{v} / \mathrm{v})\end{array}$ \\
\hline 25380 & 743 & Bogner et al., 1997a & $\begin{array}{l}\text { Field incubations } \\
\text { (Illinois, USA) } \\
\text { where initial } \mathrm{CH}_{4}<8 \%(\mathrm{v} / \mathrm{v}) \\
\text { and }>160 \mathrm{ppmv}^{-}\end{array}$ \\
\hline
\end{tabular}




\section{List of Figures.}

Figure 1. Geometric Mean Profiles for Soil Gas Methane through Landfill Cover Materials. Observed Temporal and Spatial Variations at humid Illinois (Mallard Lake, ML) and semiarid California (BreaOlinda, OL) sites, USA. Depth to top of refuse approximately $100 \mathrm{~cm}$ at $\mathrm{ML}$ and $50 \mathrm{~cm}$ at $\mathrm{OL}$. Conditions of interest given below. Corresponding measured fluxes given in Table 2.

$O L^{\prime} 88 \quad$ dry sandy silt cover soil, no gas recovery. (Bogner, 1992)

$O L$ '94 same location as OL '88 after installation of pumped gas recovery.

ML '93 (prox) compacted silty clay cover with topsoil and full vegetation. proximal includes composite 1992-1993 data from probes within $20 \mathrm{~m}$ of pumped gas recovery well.

ML '93(dist) distal includes composite 1992-1993 data from probes $>20 \mathrm{~m}$ from pumped gas recovery well. (Bogner et al., 1993)

$M L ' 94$ (prox) proximal after optimized gas recovery spring ' 94

$M L ' 94$ (dist)

$M L ' 95$ (prox) distal after optimized gas recovery spring '94. (Bogner et al., 1995) $M L ' 95$ (dist) proximal for period July-December, 1995. distal for period July-December, 1995. (Bogner et al., 1997a)

Measured methane emissions from static enclosures ranged from a high of $1115 \mathrm{~g} \mathrm{~m}^{-2}$ day $^{-1}$ (OL'88) to net oxidation of atmospheric methane, or net flux of $-0.011 \mathrm{~g} \mathrm{~m}^{-2}$ day ${ }^{-1}\left(\mathrm{ML}^{\prime} 95\right.$ dist). Note inward gradients from atmosphere at ML where $\mathrm{CH} 4<$ about $10 \mathrm{ppmv}$ in upper part of soil cover due to pumped gas recovery system.

Figure 2. Coserved Methane Oxidation Rates from a Northern Illinois Landfill, USA. Kinetic plot with composite data from field incubations and static enclosure measurements (negative flux). (Bogner et al., 1997b) 


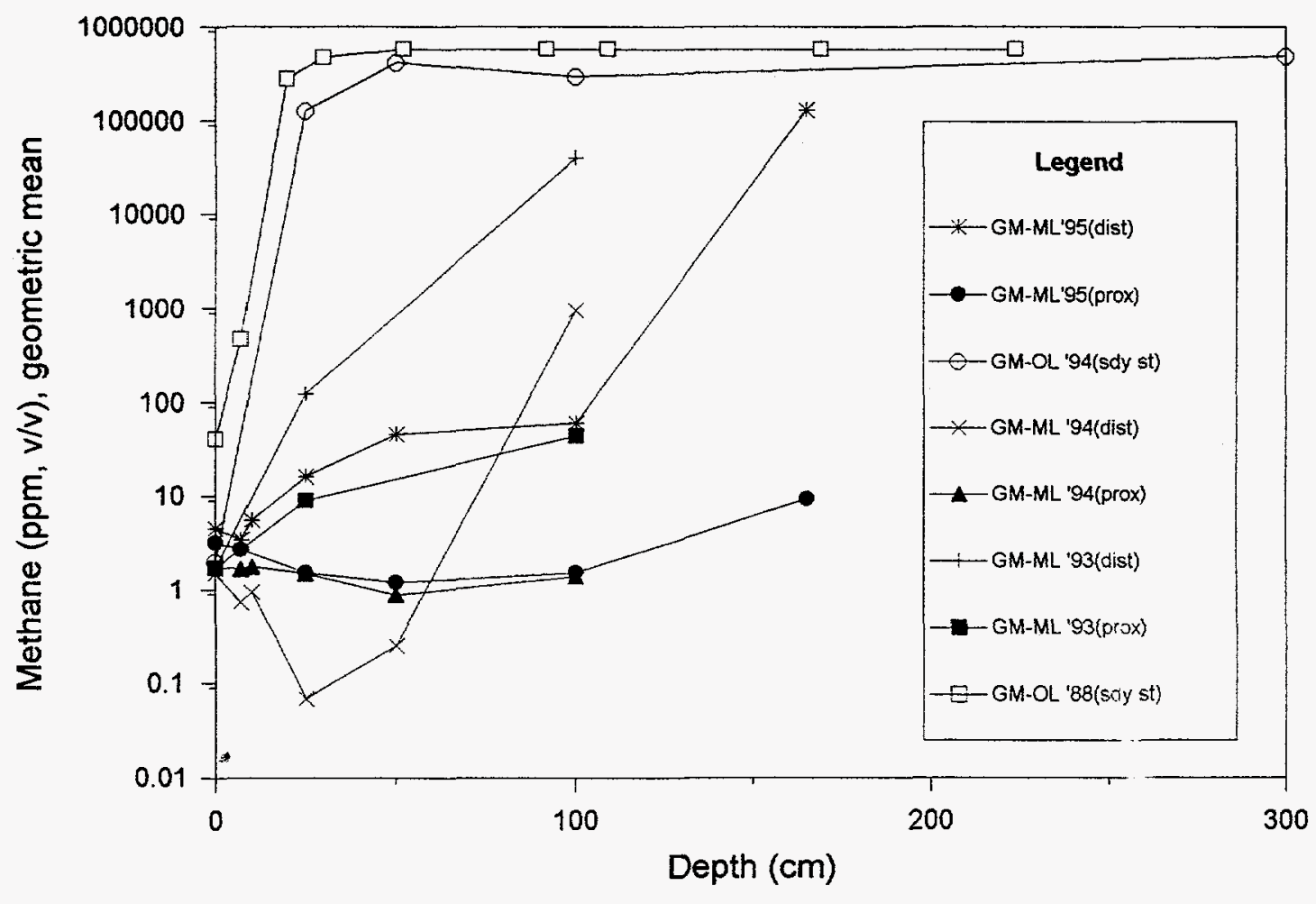




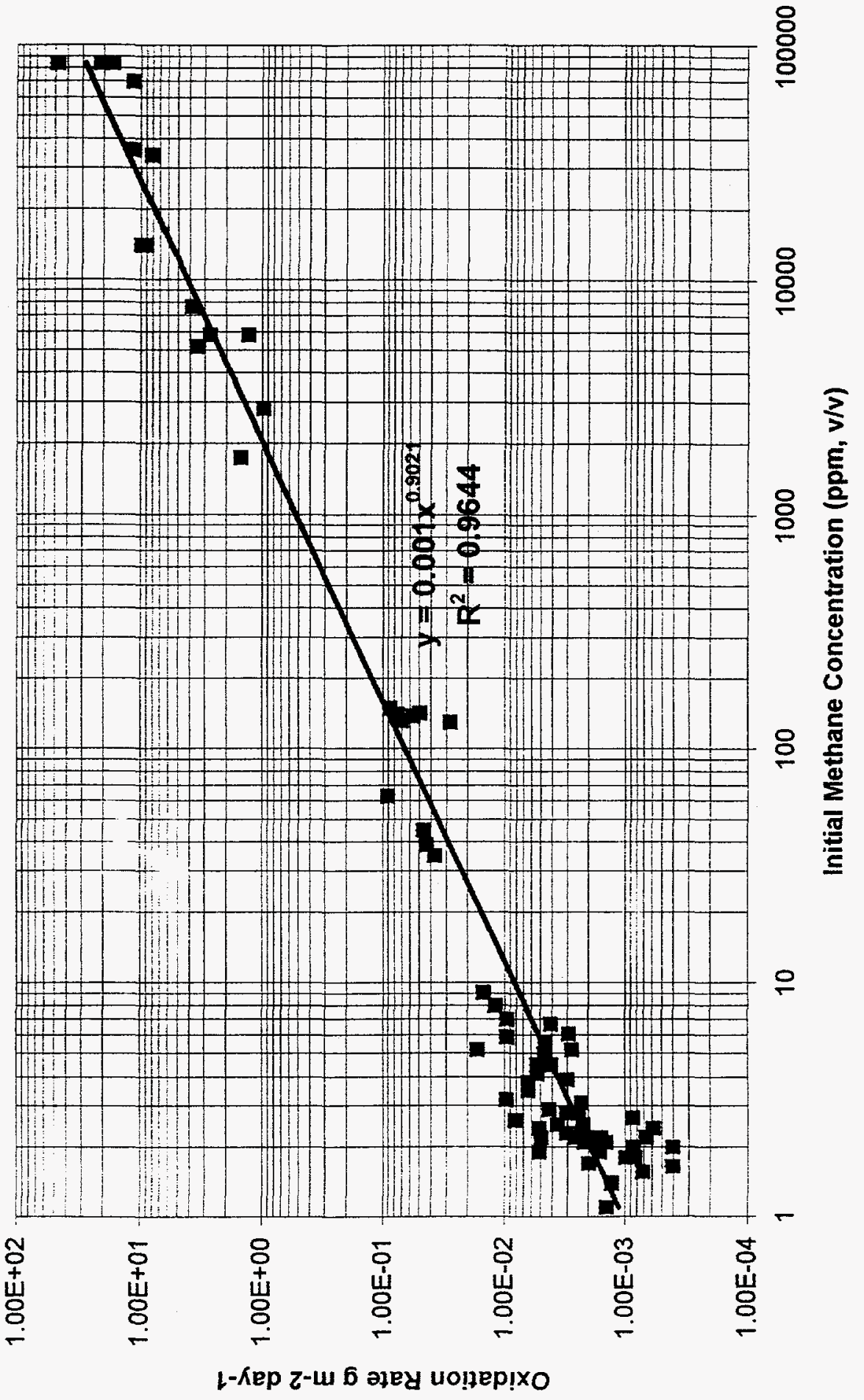

